\title{
HOMONÍMIA, MUNDOS TEXTUAIS E HUMOR
}

\author{
Luiz Carlos Travaglia
}

RESUMO: Le but de cet article est: a) l'analyse des mécanismes de lecture et l'établissement des effets de sens dans des textes humoristiques où se produit la mise en action de deux mondes textuels différents; b) le commentaire de l'influence de l'homonymie en tant que mécanisme linguistique très utilisé et productif dans ce type de texte.

PALAVRAS-CHAVE: texto, mundo textual, humor, leitura, homonímia.

On connaît quantité de définitions de l'humour, dont la plus juste est sans doute: la politesse du désespoir.

Baronian

\section{INTRODUÇ̃̃O}

Em Travaglia (1990) registramos que o humor era um campo de estudos que interessava à Lingüística. Propusemos, então, em linhas bastante gerais, os principais veios de trabalho que a Lingüística podia explorar no estudo do humor. Preocupamo-nos, ainda, em esboçar sobre o humor um referencial teórico básico que julgávamos fundamental ter em mente para manter os elementos do objeto de estudo dentro de uma dimensão adequada e para facilitar a análise de como o lingüístico atuava no texto humorístico, permitindo distinguir mais adiante o que era lingüístico do não especificamente lingüístico. Outro estudo que estrutura também este tipo de referencial é Travaglia $(1988)^{1}$, onde, analisando programas humorísticos da televisão brasileira, estabelecemos vários grupos de categorias que nos pareceram necessárias e pertinentes para análises, com diferentes objetivos, de textos humorísticos. Ao falar destas categorias, sobretudo as do grupo 6 (O que

Luiz Carlos Travaglia é professor no Departamento de Ciências da Linguagem da Universidade Federal de Uberlândia

${ }^{1}$ Este texto circulou como inédito em cópias xerox e só foi publicado em 1992. 
provoca o riso: scripts e mecanismos), exemplificamos de modo mais específico como recursos e mecanismos da língua - em diferentes níveis e planos (fonológico, morfológico, sintático, semântico, pragmático, textual e/ou discursivo, sociolinguístico, etc.) - atuam na produção de efeitos humorísticos de textos. Estes estudos representaram para nós etapas necessárias e fundamentais para a realização de estudos mais especificamente lingüísticos ${ }^{2}$.

O que está em jogo no que acabamos de dizer é a questão da relação entre Lingüística e humor. Raskin (1987) já comentava as diferentes atitudes que os estudiosos podem ter ao trabalhar com o humor: vê-lo como um campo a) para testar as teorias e métodos de seus campos b) para verificar conceitos e teorias trazendo insights sobre problemas ou c) a combinação dessas duas atitudes. $\mathrm{Na}$ relação da Lingüística com o humor acreditamos haver, para além do que já foi dito, duas possibilidades básicas:

a) usar os textos humorísticos apenas como dados pertinentes $\mathrm{e}$ interessantes para evidenciar mecanismos de funcionamento da língua. $\mathrm{O}$ objeto aqui é prioritariamente a língua e não o humor;

b) mobilizar os conhecimentos, teorias e análises lingüísticas para tentar responder a perguntas básicas no estudo do humor: O que é engraçado? Por que é engraçado? Como é engraçado? Isto representaria dizer quais mecanismos e/ou recursos da língua são usados para produzir humor e como. O objeto aqui é prioritariamente o humor e não a língua ${ }^{3}$. Evidentemente, uma possibilidade não invalida ou exclui a outra e, na verdade, a questão nos parece mais de prioridade, pois acreditamos que o estudo em uma perspectiva sempre trará contribuições para a outra, mesmo que não estejamos com o propósito específico de trabalhar dentro das duas possibilidades. Cremos que nossos estudos têm se posicionado prioritariamente dentro da possibilidade $b$.

Nosso objetivo neste trabalho é duplo: a) afunilar um pouco mais o estudo lingüístico do humor abordando doravante questões mais específicas, já que anteriormente montamos um quadro geral onde encaixá-las; b) observar e comentar como a homonímia funciona enquanto gatilho lingüístico do humor.

Utilizamos como corpus programas humorísticos da televisão brasileira e publicações de piadas em livros, revistas e folhetos e piadas recolhidas na tradição oral, nos quais levantamos um total de 70 (setenta) textos humorísticos, onde se utilizou o recurso da homonímia.

\footnotetext{
${ }^{2}$ POSSENTI (1991) reivindica que tais estudos sejam realizados.

${ }^{3}$ POSSENTI, 1991, p.492-494, preocupado com esta questão, comenta sobre o que seria um estudo lingüístico do humor. Adota a atitude $b$ de Raskin e propugna a possibilidade $a$ aqui proposta de relação da Lingüística com o humor, ao dizer que se deve demonstrar "que o humor é um campo de interesse para a Lingüística, no sentido de que, aí, pode-se fazer boa pesquisa fonético-fonológica, morfológica, sintática, semântica, sociolingüística, etc. E mesmo pragmática e discursiva".
} 


\section{HUMOR, MUNDO TEXTUAL E HOMONÍMIA}

Sabe-se que, no estabecimento do efeito de sentido que um texto é capaz de produzir entre interlocutores em uma situação de interação comunicativa, é de grande importância a ativação do conhecimento de mundo realizada pelos interlocutores a partir do material lingüístico que constitui este mesmo texto. Usando este conhecimento de mundo os interlocutores criam um mundo textual que é fundamental para o estabelecimento do efeito de sentido que ocorre e, portanto, para o estabelecimento da coerência desse texto ${ }^{4}$, de uma unidade/continuidade de sentido.

Por outro lado, sabe-se também que um dos mecanismos básicos dos textos humorísticos é a bissociação que consiste em, por recursos diversos, ativar dois mundos textuais ${ }^{5}$. Ou seja, o texto, como dizem alguns estudiosos, será compatível com dois scripts ou frames em algum sentido opostos entre si. Ora, o que ocorre então é que o texto humorístico vai trabalhar, basicamente, com mais de uma possibilidade de leitura de seqüências lingüísticas quase sempre surpreendendo o seu receptor com possibilidades não percebidas, devido a condicionamentos discursivos que privilegiam para certos co-textos e contextos (situação imediata de comunicação e contexto sócio-histórico-ideológico de uso da língua) uma determinada leitura. Entram em jogo para produzir o efeito humorístico da bissociação vários mecanismos ${ }^{6}$, entre eles o da ambigüidade que nos interessa particularmente neste estudo. O efeito humorístico advirá da descoberta de ambigüidades suspeitadas ou não.

Lingüisticamente, a ambigüidade pode resultar de uma série de recursos que não cabe enumerar aqui. Interessa-nos neste estudo apenas a homonímia enquanto recurso lingüístico que pode criar ambigüidades, resultando no mecanismo básico da bissociação, funcionando como gatilho do humor. A seguir trataremos das homonímias, mostrando algumas formas ou tipos diferentes de homonímia que podem ocorrer, exemplificando e comentando alguns exemplos na tentativa de explicitar como as mesmas funcionam para o estabelecimento do efeito humorístico.

\section{HOMONÍMIAS}

Pode-se dizer que ocorre homonímia quando dois signos (palavras, expressões, frases, etc.) têm em seus significantes fonias idênticas (ou semelhantes, se preferirmos lembrar que duas fonias nunca são exatamente iguais). Ao

\footnotetext{
${ }^{4}$ Cf. KOCH e TRAVAGLIA (1989 e 1990).

${ }^{5}$ Cf. o que dissemos sobre bissociação em TRAVAGLIA (1990), sobretudo às págs. 76 e ss.

${ }^{6}$ Como a ironia, mistura de lugares sociais ou posições de sujeito, ambigüidade, contradição, sugestão, descontinuidade ou quebra de tópico discursivo, paródia, desrespeito a regras conversacionais, violação de normas sociais (cf. TRAVAGLIA, 1988).
} 
observarmos textos humorísticos, que se utilizavam da homonímia como recurso, pudemos detectar alguns tipos de homonímias que podem ser identificados como segue:

Tipo 1: Palavras idênticas: o que temos são duas palavras homófonas e/ou homógrafas que através de uma só fonia podem ativar dois significados/sentidos diferentes. É o tipo mais freqüente $(48,57 \%$ no corpus analisado). Vide exemplo (1).

(1) Cuidado

A velhinha senta-se no banco da frente do ônibus e bota uma sacola de papel no banco ao lado. O ônibus continua seu percurso. Pára no ponto seguinte e entra um cara. O único lugar vazio era aquele ao lado da velhinha. Quando ele vai se sentando, a velhinha grita:

- Cuidado com os ovos!

O homem dá uma parada e descobre a sacola de papel em cima do banco. Gentilmente, pega a sacola pra devolver pra velhinha. Aí, sente o peso da sacola e diz:

— Mas, isto são ovos?

E a velhinha:

— Não! São pregos!

(Almanacão de piadas, n.5).

Tipo 2: Palavra/sequiência: o que acontece aqui é que uma palavra é homônima de uma sequiência, ou seja, a palavra é percebida pelo usuário da língua como podendo ser recortada, equivalendo a uma série de palavras. A freqüência no corpus analisado foi de $28,57 \%$. Vide exemplo (2).

(2) Cena: Os humoristas representam repórteres fazendo uma matéria sobre o amor. Abordam várias pessoas na rua perguntando:

- Meu amigo, você está amando?

Num dado momento um deles se aproxima de um guarda de trânsito na rua e faz a pergunta ao que o guarda responde:

- Sim, estou a mando do Coronel Cerqueira e ele disse que não pode gravar entrevista aqui. Vai andando.

(Casseta \& Planeta, 18/01/94. Rede Globo de Televisão).

Tipo 3: Duas seqüências homônimas: Este tipo é quase sempre um tipo híbrido, pois quase todos os exemplos, encontrados no corpus analisado, podem ser também interpretados como homonímia entre uma expressão idiomática e uma seqüência que não é expressão idiomática. Dois exemplos onde este tipo fica bem evidenciado são os transcritos em (3). A freqüência no corpus foi de 10,00\%.

(3) a) Apresentadora:

—E aí, mané? Que time é teu?

(Casseta \& Planeta, 28/12/1993, Rede Globo de Televisão).

b) Coisa estranha...

Faz um tempão que aquele sujeito de tamancos e bigodes está ali, esfregando uma moedinha na calçada. Alguém pergunta:

— Que diabo o senhor está fazendo, afinal?

- Gastando dinheiro, pá! 
Tipo 4: Homônimos com mudança de classe: É o caso em que as duas palavras são iguais, mas pertencem a classes diferentes (substantivo/verbo, substantivo/adjetivo, verbo/adjetivo, etc.). Tem-se, neste caso, o que se chama de conversão morfológica. Se o usuário percebe a palavra como sendo de uma classe, o texto terá um sentido, se a percebe como de outra, o texto terá outro sentido. A frequiência no corpus foi de $7,14 \%$. Vide exemplos de (4).

(4) a) $O$ suicida

Último bilhete deixado por um obstreta: parto sem dor.

b) cena: Humorista caracterizado de traficante diz o seguinte:

(QUINTANA, 1987, p.48).

O traficante carioca obedece a um código de honra: ou mato ou morro... Ou seja, ou ele se esconde no mato ou ele se esconde no morro.

(Casseta \& Planeta, 08/02/1994, Rede Globo de Televisão).

Tipo 5: Expressão idiomática $X$ mesma seqüência não funcionando como expressão idiomática: Aqui o que temos é a mesma sequiência de termos, sendo usada ou não como uma expressão idiomática. A freqüência no corpus foi de $20,00 \%$. Vide exemplos de (5).

(5) a) Conversa de jacaré

No Pantanal, enquanto tomam sol, um jacaré diz pro amigo:

- Meu pai tá cheio de grana!

-É mesmo? E o que ele faz?

— Nada... Fizeram uma carteira com ele!

b) Questão de preço

(As melhores do Costinha, n.5, p.53).

$\mathrm{O}$ viajante chega naquela cidadezinha perdida no interior de Minas e estranha a diferença de preços do hotel: diária de duzentos mil, cem mil e dez mil cruzeiros. O capiau que tá na portaria explica:

- No quarto de duzentos mir, o senhor tem direito à tevê, vídeo, sauna. $\mathrm{O}$ de cem mir num tem sauna. No quarto de dez mir, vai tê de fazê $a$ cama!

$\mathrm{O}$ viajante não tem dúvida:

— Fico nesse! Sei fazer a cama!

E o caipira:

— Pode pegá a madeira, os prego e o martelo ali nos fundos!

(Almanacão de piadas, n.5, p.112).

Tipo 6: Homônimos com diferenças sintáticas: Neste caso tem-se um termo que adquire sentidos diversos conforme o co-texto. A frequiência no corpus analisado foi de $12,86 \%$. Vide exemplos de (6).

(6) a) Cena: O humorista entrevista as pessoas na rua sobre suas vocações profissionais:

- Você dá para artista?

(Casseta \& Planeta, 18/01/1994, Rede Globo de Televisão).

Aqui tem-se uma espécie de pega: alguns entrevistados respondem que sim entendendo que elas têm talento para serem artistas. Neste caso o humorista insinua a segunda leitura (entregar-se em relação sexual a um artista) e riem do entrevistado ou junto com ele que também ri, ao perceber que caiu no pega. Outros 
entrevistados já percebem o segundo sentido, e, rindo, respondem que não.

b) Regime lusitano

Seu Manuel andava muito gordo e procurou um médico especialista em regimes. E o doutor recomendou:

- O senhor deve comer normalmente durante dois dias. Depois, pule três dias e repita o mesmo durante duas semanas! Quando retornar, terá perdido pelo menos três quilos!

Pra surpresa do médico, quando seu Manuel voltou ao consultório, tinha emagrecido mais de dez quilos! Espantado, o médico pergunta:

- O senhor conseguiu perder dez quilos só seguindo as minhas instruções? Mas isso é surpreendente! Incrível! Nem eu imaginei que isso fosse possível!

E o seu Manuel:

— Ora, pois... Foi sim! Só que no terceiro dia, pensei que ia morreire!

- De fome?

— Não... De tanto pulaire!

(As melhores do Costinha, n.5, p.36).

Nos casos em que temos homonímia com diferenças sintáticas, pelo menos para o humor é interessante observar o papel das posições vazias que reforçam a possibilidade de dupla leitura ao criarem junto com a homonímia a possibilidade de mais de uma leitura. Em (6a) na interpretação sexual o objeto fica vazio e para artista é o destinatário, enquanto em (6b) não há posição vazia. Em (6b), conforme a interpretação três dias será o objeto ou o adjunto adverbial indicador da duração de pular. Aqui há uma ambigüidade estrutural (sintática) resultante da ambigüidade lexical, dada pela homonímia.

Tipo 7: Falsa homonímia: reservamos este nome para aqueles casos em que não se tem verdadeiramente homônimos, mas os usuários da língua fazem com que o texto funcione como se houvesse um homônimo. Isto ocorre, normalmente, por ignorância (Exemplo 7a) ou por não ouvir bem (Exemplo 7b). Evidentemente, todos os exemplos deste tipo são exemplos também de algum dos outros tipos, todavia quisemos colocar este caso à parte porque ele utiliza sempre o script humorístico da ignorância. A freqüência no corpus analisado foi de 4,29\%. Vide exemplos de (7).

(7) a) Bão de leitura

O Tonho e o Zé vão pra cidade depois de muito tempo só entocados no mato. Chegam a uma ruazinha estreita, onde tem uma placa onde está escrito: Proibida a passagem de veículos.

Tonho aperta os olhos e diz:

- O cumpadre qui é mais bão das vista do qui eu, lê o que tá escrito ali!

O outro se concentra e balbucia:

— Deixa vê... Puro... puro...i...bida... a pa... sa... di... ve... ve... i...co!

— Que quer dizê isso?

- Acho qui é... Proibida a passage di veíco!

— I nóis semo veíco?

- Acho qui sim... Tudo mundo qui passa dos sessenta é veíco, sô!

E o Tonho conclui: 
— Intão nóis num podemo passá!

b) Bichinha respondona

(Almanacão de piadas, n.5, p.68).

E a bichinha tava lá no trigésimo-quinto andar do edifício Itália, esperando o elevador. A porta se abre e o ascensorista pergunta:

- Desce?

E a bichinha:

— Dei, sim! E dou quanto eu quiser! Que qui cê tem com isso, bofe?

(Almanacão de piadas, n.5, p.102).

É importante observar que um mesmo exemplo de homonímia pode pertencer a mais de um tipo, sobretudo porque os tipos foram estabelecidos segundo critérios diferentes: a) os tipos 1 a 3 têm a ver com a quantidade de palavras que constituem o elemento homônimo ao outro (palavra ou seqüência de palavras); b) os tipos 4 (classe da palavra homônima) e 5 (a seqüência é uma lexia complexa ou um sintagma) têm a ver com um critério morfológico ou morfosintático); c) o tipo 6 é derivado de um critério sintático ou sintático-semântico e d) o tipo 7 é estabelecido por um critério extralingüístico.

O funcionamento básico de todos esses tipos de homonímia em textos humorísticos advém da possibilidade de ativação de mais de um mundo textual e, portanto, de mais de uma leitura. Este não é um mecanismo exclusivo dos textos humorísticos, mas funciona como gatilho do humor, com freqüência associado a outros recursos lingüísticos ou não e funcionando dentro de scripts humorísticos ${ }^{7}$ de nossa cultura e numa situação de interação comunicativa que se apresenta como humorística, o que dissemos alhures ser fundamental para que recursos diversos funcionem para a produção de efeitos humorísticos de sentido. Embora o funcionamento básico seja sempre o mesmo, a homonímia parece apresentar três modos distintos de atuar na constituição do texto e na produção do efeito humorístico. No primeiro deles, levando em conta a situação de interação em curso entre os personagens da piada, a homonímia leva a/permite uma leitura equivocada por um dos personagens da fala do outro. O equívoco, normalmente, só é percebido pelo personagem no desenrolar da situação, o que funciona como gatilho para o humor (Vide exemplos 1, 5a, 5b). É comum que só o receptor da piada perceba a leitura equivocada. Neste caso o personagem permanece no equívoco, entrando em ação o script humorístico da ignorância ou estupidez (Vide exemplo 6b). Às vezes não há propriamente um equívoco, mas o texto é construído como se um dos personagens ignorasse o contexto e a área do conhecimento de mundo em que o discurso está centrado e, então, diz algo ou responde uma pergunta tomando um sentido do homônimo e não o outro que seria pertinente na interação e com o qual o interlocutor o empregou (Vide exemplo 8a). No segundo modo a homonímia também leva a/permite uma leitura equivocada, mas agora apenas pelo leitor/ouvinte da piada. Este vai rir quando perceber a outra possibilidade de leitura (Vide exemplo 4b). Neste modo podemos incluir o funcionamento dos pegas em que o receptor do texto, se perceber apenas a leitura não comprometedora do

${ }^{7}$ Cf. TRAVAGLIA (1988). 
homônimo, cai no pega provocando o riso pelo script da estupidez; e se perceber também a leitura comprometedora ri da descoberta antes de ficar como tolo dentro da interação, o que poderá ser subsumido pelo modo seguinte (Vide exemplos 3a e 6a). Finalmente, temos os casos em que o humor surge não de leituras equivocadas, mas da simples mistura de dois mundos textuais ativados pela homonímia e cuja percepção pelo receptor do texto é o móvel do humor (Vide exemplo 2, 3b, 4a, 8c). Às vezes tem-se a aproximação explícita dos dois homônimos no mesmo texto criando o efeito humorístico (Vide exemplo 8b).

(8) a) - Você deu corda no relógio?

- Hoje cedo. Ele estava parado.

- Claro! Você já viu algum relógio andando por aí?

b) O casal de namorados está no escuro no maior amasso. De repente, um policial se aproxima e a mocinha diz:

- Olha o guarda, guarda.

Isto é a mocinha brasileira. A mocinha americana quando vê o policial diz para o namorado:

- Olha o tira, tira.

e) Relógio que atrasa não adianta.

(Exemplos recolhidos da tradição oral).

Um exemplo como o de (7a), evidentemente implica considerações fonético/fonológicas. Este é também o caso do exemplo (9) que, na forma escrita, permite três leituras diferentes a partir da seqüência "Rosário, a pinga" que poderá: a) ter dois sentidos diferentes, se o leitor (ou narrador) fizer uma entonação de enumeração: Rosário = objeto para rezar e Rosário $=$ a mulher. Esta segunda possibilidade só aparece quando surge a seqüência "Rosário, traz essa pinga logo!"; b) um só sentido, se devido à sequiência "Rosário, traz essa pinga logo!" o leitor der à sequiência "Rosário, a pinga" uma entonação de comando, de ordem. Esta evidentemente não é a entonação pretendida aqui, primeiro porque a expressão "Depois, grita" corta a possibilidade de "Rosário, a pinga" ter a entonação de comando que dissemos ser possível e segundo, porque o texto só será humorístico com a primeira entonação que permite ativar conhecimentos de mundo diversos, criando dois mundos textuais e chegando a duas leituras diversas: uma comprometedora para o padre (a vida dele é sexo e bebida) e a outra aceitável pela sociedade (a vida dele é rezar e beber algumas pingas) ${ }^{8}$. Isto evidencia como a possibilidade das duas leituras, permitida pela homonímia, é fundamental para que o texto humorístico se constitua e funcione enquanto tal.

(9) Papo de padres

O padre de uma cidade perdida no meio do mato vai visitar o colega da paróquia vizinha:

— Então, padre Luís? Como vão as coisas? Muito movimento?

— Que nada! A mesma vida de sempre... Rosário, a pinga...

Depois, grita em direção à cozinha:

\footnotetext{
${ }^{8}$ Já registramos em TRAVAGLIA (1990) que os dois mundos textuais ou scripts são sempre opostos em algum sentido especial. É o que ocorre aqui, não só neste exemplo, mas em todos os demais. No exemplo (8) a oposição é sexo (comprometedor, inaceitável)/não sexo (aceitável).
} 
— Rosário, traz essa pinga logo!

(Almanacão de piadas, n.5, p.13).

A análise feita neste estudo deixa evidenciado que a homonímia, enquanto recurso lingüístico (associada ou não a outros elementos do texto) funciona, nos textos humorísticos, como gatilho que permite e faz a mudança de um mundo textual para outro ${ }^{9}$ e como faz isto: pela possibilidade de ativação de conhecimentos de mundo diferentes que resultarão em mundos textuais distintos e opostos em algum sentido e que são ambos compatíveis com o texto tal como ele está constituído.

\section{CONCLUSÃO}

Uma idéia importante que não se pode deixar de registrar é que dentro do trabalho de ensino de Língua Materna em $1^{\circ}$ e $2^{\circ}$ graus, os textos humorísticos são um recurso didático bastante interessante no desenvolvimento da competência comunicativa dos alunos enquanto receptores de textos, para deixar claro fatos fundamentais envolvidos na leitura (de textos orais ou escritos de qualquer tipo):

- que uma seqüência linguíística tomada como texto pode ter várias leituras (pode produzir mais de um efeito de sentido), conforme se variem as condições de produção da leitura;

- que certos efeitos de sentido são vistos como únicos porque privilegiados por condicionamentos da exterioridade sócio-histórica, cultural e ideológica, mas na verdade há outras possibilidades para além do discurso dominante;

ou seja, o texto humorístico é capaz de deixar evidente, de uma forma agradável, fatos importantes do funcionamento discursivo dos textos e dos recursos da língua, o que sem dúvida é interessante para a pesquisa lingüística que tem nos textos humorísticos evidências bastante explícitas de tais fatos.

\section{BIBLIOGRAFIA}

BARONIAN, Jean-Baptiste. Humour... de rire et de pleurer. Magazine Littéraire, Paris, n.312, p.6-8, Juillet-Aoút. 1993.

KOCH, Ingedore G. V.; TRAVAGLIA, Luiz C. Texto e coerência. São Paulo, Cortez, 1989. . A coerência textual. São Paulo, Contexto, 1990.

POSSENTI, Sírio. Pelo humor na Lingüística. DELTA, São Paulo, PUCSP/ABRALIN, v.7, n.2, p.491-519, ago. 1991.

RASKIN, Victor. Semantic mechanisms of humor. Dordrecht and Boston, D.

\footnotetext{
${ }^{9}$ De um script para o outro, no dizer de RASKIN (1985, 1987a).
} 
Reidel, 1985. (Synthese Language Library, 24).

. The interdisciplinary field of humor research. Semiotica, Amsterdam, Mouton de Gruyter, v.66, n.4, p.441-444, 1987.

. (1987a). Linguistic heuristics of humor: a script based semantic approach. In:

APTE, Mahadev L. (ed.). International Journal of the Sociology of Language.

Berlin/New York/Amsterdam, Mouton de Gruyter, v.66, n.4, p.11-25, 1987.

TRAVAGLIA, Luiz Carlos (1988). O que é engraçado?: Categorias do risível e o humor brasileiro na televisão. Leitura: estudos lingüísticos e literários, Maceió, Universidade Federal de Alagoas, n.5, 6, p.42-79, 1992.

- Recursos lingüísticos e discursivos do humor: humor e classe social na televisão brasileira. In: Estudos lingüísticos/XVIII anais de seminários do Grupo de Estudos Lingüísticos do Estado de São Paulo, Lorena, Prefeitura Municipal de Lorena/GEL-SP, $2^{\circ}$ sem. 1989. p.670-677.

. Uma introdução ao estudo do humor pela Lingüística. DELTA, São Paulo, PUC-SP/ABRALIN, v.6, n.1, p.55-82, fev. 1990.

\section{CORPUS}

A rosca: piadas e anedotas. São Paulo, Fittipaldi Ltda., n.2, s.d.

Casseta \& Planeta: Programa humorístico reapresentado pela Rede Globo de Televisão em 28/12/1993. (Gravado em vídeo).

Casseta \& Planeta: Programa humorístico reapresentado pela Rede Globo de Televisão em 18/01/1994. (Três textos transcritos durante a apresentação do programa).

Casseta \& Planeta: Programa humorístico reapresentado pela Rede Globo de Televisão em 08/02/1994. (Gravado em vídeo).

CAZZAMATTA, Carlos; LIMA, Paulo P. (eds.). Almanacão de piadas, São Paulo, Nova Sampa, n.5, s.d.

CAZZAMATTA, Carlos; LIMA, Paulo P. (eds.). Almanaquinho n.3: Piadas de Portuga, São Paulo, Nova Sampa, s.d.

CAZZAMATTA, Carlos; LIMA, Paulo P. (eds.). As melhores do Costinha, São Paulo, Nova Sampa, n.5, s.d.

O gozador: especial: humor, piadas, anedotas, cartuns. São Paulo, Fittipaldi Ltda., n.39, s.d.

QUINTANA, Mário. Da preguiça como método de trabalho. Rio de Janeiro, Globo, 1987.

ZIRALDO. As melhores anedotas do mundo (recolhidas, colecionadas e recontadas por Ziraldo). Rio de Janeiro, Globo, 1988. v.1. 